\title{
The Study of Spiritual Heritage of Khoja Ismat Bukhari
}

\author{
Raupova Rano Soibovna ${ }^{1}$, Nazarova Gulshod Hodjievna ${ }^{2}$ \\ ${ }^{1}$ Islamic History and the department of philosophy, Bukhara State University, \\ Uzbekistan \\ ${ }^{2}$ The teacher of chair of foreign languages, Bukhara State University, Uzbekistan \\ Email:raupova_r@umail.uz
}

\begin{abstract}
This article analyzes Hoja Ismat Bukhari, a great thinker and poet who lived and worked in the Temurids Palace in the 14th century, and his rich scientific and spiritual heritage. It also provides valuable descriptions of the authors, the study of these works, and their preservation in the world's prestigious libraries.
\end{abstract}

Keywords: Khoja Ismat Bukhari, Devone Khoja Ismat Bukhara, Khoja, Majolis un nafois, Ibn Arabshah, State Shahriq, Tazkirat Usha, Devon, Khondamir, Habib-us-Siyar.

\section{INTRODUCTION}

With the development of science, the doctrine of Sufism in Central Asia has developed and its various directions have emerged - Turkestan in the 12th century, Cubravity in Khorezm at the end of the 12th century, and patterned in Bukhara in the 14th century. During this time, the architecture of Central Asia also developed. Dehgaron, Masjid Kalon, Namokgoh, Magogoki Attori mosques in Bukhara, Jarkurgan Tower in Surkhandarya, Fakhriddin Rozi's mausoleum in ancient Urgench, Sultan Sanjar's mausoleum in Merv, Hojanbobo mosque and other memorable examples of architectural art. "In the Timurid era, Central Asia made a worthy contribution to world civilization. Great people, such as Lutfi, Atoyi, Gadai, Sakkoki, Abdurahman Jomiy, Mirzo Ulugbek, Ali Kushchi, Alisher Navoi, Behzod, Sultan Mashhadi, Mirzo Babur, Davlatshah Samarkand, Ibn Arabshoh, Khondamir were born and blessed. . However, from the beginning of the fifteenth century the great country, created by Amir Temur, also came into political crisis. Khoja Ismat became a respected person during these historical events. Therefore, he was in the focus of the Timurid household, and at the same time witnessed the social and political changes in his time. It is important that his creative activity can be evaluated not only socially and philosophically, but also as a political person. After all, Khoja Ismat Bukhari had a special place in this historical process.

Khoja Icmat was one of the descendants of Bukhari's imam Ja'far Jadik Born in Bukhara to a noble and noble merchant family. From an early age he was distinguished from his childhood by his clever, cheerful, cheerful and delicate man, because of his keen intelligence, his abilities, and his upbringing.

Alisher Navoi in detail on Majolis un-nafois and Mezon ul-avzon about Khoja Ismat Bukhari in detail. He explains that in the Majolis-un-nafois, he added that he was one of his predecessors, and that "Hodja Ismat Bukhari was one of the nobles of Maveraunnahr ... the famous devil's poet was famous" and created an unparalleled example. "Zahir has perfected knowledge. The poem itself became famous because of its extraordinary beauty... The grave of Khoja is in her cell in Bukhara". Khoja Ismat Bukhari is indeed one of the most widely recognized "Movarounnahr breeders" in all historical sources. The separate devotions of Khoja Ismat Bukhari, number 25-9260, 805-X, 1435, 2236-X1, 4313-1, currently stored in the manuscript collection of the Academy of Sciences of Uzbekistan, published by Ahmad Karami in Iran. an excellent collection of poems, the poem "Avvali zuhuri dwuyu devoni Khoja Ismat", preserved in the Central Library of Bukhara region, is a major part of historical sources that inform the writer's creative work and life. In particular, some of his works have 
been translated into a number of foreign languages. As Rustamov noted in the 1970s, "Khoja Ismat Bukhari as a poet of the Timurid palace has not gone unnoticed by foreign Orientalists."1

\section{THEORITICAL BACKGROUND}

Czech scholar Jan Ripka, German orientalist Hammer, Iranian literary critic Ehsan Yorshoshir highly valued his art. Russian scientist A.Krimsky pays special attention to the important aspects of the poet's work. In the book "The History of Iranian Literature," the English orientalist Edward Brown acknowledged that the State King relied on the "Tazkirat-ush-sharo" and coached Hodja Ismat Hayali Buhari and Bisothi Samarkand, and was the founder of Rustam Huryanani, Tahir Abeardi and Burundi Bukhari.

The first source for the study of the poet's life and work is the work by Davlatshoh Samarkand, "Tazkirat-ush-shuaro". In the sixth chapter of the book, Khodja Ismat is considered to be one of the "noble people" and says that she is "singular in poetry" among other poets in "poetry, ghazalah, masnavi, muqattaat and other" poetic genres. and in some cases added myths and legends. In verse 7 of Abdurrahman Jami's "Bahoriston", "Khoja Ismatullah is from Bukhara and Amir Khusrav is the supporter of the ghazal of Delhi." The word "Khoja", used in the poet's name, refers to his lineage. The birth date of this breeder is recognized in almost all research sources between 1365 and 1375 .

Kajzabuddin Safo writes in "Historical Literature Iran": "He used two pseudonyms in his works. One is Ismat and the other is Nasiri. As a rule, Tazkirah had a reputation for its name, Ismat (Ismatullah), and it became a pseudonym. ... However, he derived his poetic pseudonym from Temur's ancestor Nasiruddin Khalil. The fact is that Nasiriy nicknamed his name and sometimes "Ismat". He used it in his ghazals because the word Ismat was shorter and more appropriate.

In the book Habib-us-Siyar, Khondamir, among the literary writers, gives information about Hodja Ismat, in particular, about her death:

Khoja Ismat, the deceased Anyway, you know: "tammat"

\section{MAIN PART}

The author notes that the word "tammat" coincides with the abjad 840 (1436 CE), and adds in this work the views of Abdurahman Jami and Kajzabiddin Safa: "The State wrote the death of its history 829 and Tafiddin repeated the same. more than any other in his creative work, he has been a successor to Kamal Khojandi, and the same comment has been made in the "Mahzanun Wonderland".

Professor A.Semyonov clarified the history of Mullah Sharofiddin Ibn Alam's "History of the Kassira". He said that he had been charged with Hodja Ismat, calling him "goddess Salotin," the goddess of the kingdom, and had left the Ulugbek Palace and decided to stay away.

Sherkhan ibn Ahmed Ludi, in the work of Mirzot-ul-Hayill, mentioned by Persian-Tajik poets, described the "marauder and fasil, the poet of all times, as a complete piece of poetic art" repeats.

Lutfalibek Ozar's book "The Ceasefire" gives a more detailed account of the biography of Khoja Ismat Bukhari and states that the poet's ancestor died in 829. It is clear that this work was based on the Tazkirat-ush-shuaro by Davlatshahi Samarkand. In it Khodja Ismat notes that Sayfiddin Herod, Duohani, Rashidiy, Shahobiddin Ahmad, Amir Muizizi were poets of Samarkand and Bukhara. ${ }^{2}$.

Husainkulihan Azimabad ibn Ako Alkhan in one of the most beautiful tazir of XIX century in the book "Nishari love" emphasizes information about the poet's father. Amir Khisrav has a presence in Delhi. Sultan lived in peace during the reign of Khalil ibn Miranshah. In his work "Temurnoma" Salahiddin Toshkandi proves that he wrote a lamentation on the death of Amir Temur.

Ibn Arabshah, a well-known Timurist historian, wrote in his book A wonderfulul Maqrur, "Hoja Ismatiddin used to be with the Emir (Khalil Sultan), who taught him the secrets of literary science and earned him respect. However, Khalil Mirza's command in Samarkand was short, and he was soon imprisoned by his emirs in the fortress of Shahrukh. Khoja Ismat, who was beside the Khalil Sultan, left the town in desperate need of his own life and fled for nearly two years until another benefactor invited

\footnotetext{
${ }^{1}$ Рустамов Э.Р. Узбекская поэзия в первой половине XV века, -М.: Просвешение, 1963. -34 с.

2 Самарқандий, Давлатшох. Тазкират-уш-шуаро. ЎзРФА. Абу Райхон Беруний номидаги Шарқшунослик ин-ти кўлёзмалар фонди. № 53. -361 в.
} 
him to the palace. Shahrukh invited the "baroque baby" to his story after he took over the throne of Samarkand. ... Ismat remembered many good deeds from the unexpected death of the benefactor and ... made a short trip to Bukhara. When the crusades came to an end, Amirzoda Ulugbek, a wise writer of mathematics, listened to her and invited her to Samarkand."

Ahmad Karami attempted to summarize the latest information about Hodja Ismat. Ahmad Karami produced and published a collection of more than 15,000 works by Khoja Ismat in Tehran in 1987 by Ishkon Publishing House. The relatively perfect preface "Devone Khoja Ismat Bukhara" deals with the genealogy of the poet and points out that Bukhara belongs to the Ja'far bin Abu Talib from the Sharif family. Khoja's own genealogy, in recognition of his ancestry in the title of "Admiral Believer Ali Eid al-Islam," provides a particular example:

"Although, the name is Ismat, but little by name

Both Z-o-Ja'far Astu and Zi Murtazo. "

That is, "Whatever you say, the name is Ismat (purity), but it is from the lineage of Ja'far and Murtazo."

Ahmad Karami has used this in his ghazals since the fame of the poet's ancestors reached Bukhara in his days and became a reputable person, sometimes nicknamed Nasiri and now his name Ismat, and the word Ismat was shorter and more appropriate. " in detail.

Ahmad Karami quotes Tazkiratul Shararo in the Devon preface and evaluates his talent as follows: "The ghostly and ghostly words of Khoja Ismat have so great a glory in the palace of Shahrukh that it cannot be read or recited." ."

He notes that "this genre is the first example of the ancient radical Bahri Tavills" and describes it as "Amir Vazi's birthday in terms of weight gain". Ahmad Karami goes on to state his thoughts in this way and notes that Khadia Ismat, a ghost of poetry, reminisces the poet Oshik Isfahani. Although he was not as prominent as Hafiz in the ghazal world, Ali ibn Talib, who sang his first act of devotional writing to Allah, described Ali Usman as a popular "alien" under the pseudonym "Mu'iddin". This description indicates how popular Ismat Bukhari is among poets.

"As a result of the analysis of the sources, it was possible to find new information about the poet's family. According to this, Hodja Ismat was the father of five children: her four sons (Fathullah, Jura, Beck, Niyaz) were prematurely divorced and their daughter was transferred to the Temurid Ibrahim Sultan. But his daughter was divorced because he had no children. The poet, who suffered most from the stigma of his children, left the palace early and preferred to live in poverty in his native Bukhara. ". 3

Hodja Ismat Bukhari is mentioned in dozens of Tazkirahs, and the famous historians and writers have been honored for centuries not only in Movarounnahr, but also far abroad, and most importantly, he was recognized as a teacher and educator in the Timurid palace for many years. proves his prestige as a famous poet and wise man.

The socio-political, historical and cultural life of Central Asia in the XIV-XV centuries was complex and full of contradictions.

\section{DISCUSSION}

After the death of Amir Temur, feudal wars, conflicts and political conflicts between the Temurid princes and the struggle for the crown ruled the Temur empire. In the distant lands captured by Amir Temur, independent statehood was established and it gradually began to separate from Movarounnahr. Khoja Ismat Bukhari witnessed this humorous history, and this fact had a significant impact on his life and creative activity. Khoja Ismat served the interests of the society and the state in the ranks of the most progressive, educated and thinkers of her time. The poet's family genealogy indicates that the service of the palace was a father-in-law because of his long career as a propagandist in public affairs and gained the recognition of historians and editors.

Amir Temur and the Temurids lived in the late 14th and early 15th centuries. At the time, he was well-known as a talented poet. Many critics of the poet's creativity and personal qualities, including Davlatshah Samarkand, Abdurahman Jami, Alisher Navoi, Khondamir, Ali Taqidun Koshani, Amin Ahmed Rozi, Abdullo Kabuliy, Mullo Sharofiddin ibn Alam, Sherkhon ibn Ahmad Ludi, Lutfalibek

${ }^{3}$ Бобокалонов С. Хўжа Исмат шериятининг бадиияти ва жанрий хусусиятлари. Ном.дисс. Сам., 2011. 
Azar, Husainkulih Alihan Jahnbadi, Shamsuddin Simi, Salahuddin Toshkandi and others also paid special attention to their works.

\section{CONCLUSION}

The following comments of the First President of Uzbekistan Islam Karimov are rightly related to Khoja Ismat Bukhari: "The sacred hills of those who have dedicated their lives to faith and faith, patriotism and humanism, purity and integrity, knowledge and enlightenment, justice and piety are sacred. If there were no such people, and the genius of their genius would not be felt, then any earth would be just plain earth. $" 4$.

\section{REFERENCES}

1. Bobokalonov S. Art and genre features of Khodja Ismat's company. Nom.diss Sam., 2011.

2. Navoi A. Perfect collection of works. 20 drops. 13 lbs. Majolis is un-nafois. -T .: Science, 1997.

3. Navoi A. Majolis-un-nafois, Works. Volume 12, Tashkent, 1966.

4. Rustamov E.R. Uzbek poetry in the first century XV veka, -M .: Prosveshenie, 1963.

5. Krymsky A. Istoriya Persii, eyo literatury and dervisheskoy teosofii. M.: Nauka, 1971.

6. Tajik Encyclopedia of Literature and Art. Volume 1, Dushanbe, 1988, p.520. Karaev T. Khodja Ismatullo Bukhari. Bukhara 1990.

7. Scholar Sultanmurod. Khoja Ismat Bukhari / Sina (Quarterly Journal of Scientific, Literary, Philosophical and Irfonic, Spiritual and Educational Studies, Winter 2007), Issue 28,

8. Vohidov R. Khoja Ismatullo Bukhari is a poet of Zullyisonayn / The Bukhara State University. Bukhara, 2006. No. 4

9. Mirsafoev A. Xodja Ismat Bukhari и ego tvorchestva. DKN. Samarkand, 1971.

10. Samarkand, State King. Tazkirat-shu-shuaro. Uz.RFA. Fund of Manuscripts of the Abu Rayhan Beruni School of Oriental Studies No. 53. - 361 c. See also:

11. Ibn Arabshah. Wonderful Al-Maqdur fi History Taymur (Wonders of Fate in the History of Timur) Translated from Arabic and Commentary, Preface to U. Prepared by Uvatov. Responsible editor A. Urinboev. K.1. -T. : Labor, 1992.

12. Bukhari, Khoja Ismat. Devon. - Tehran: Tolorkitob. Get ready for publication. Ahmad Karami. 1987.

13. Buhari, Khoja Ismat. Devon. - Tehran: Ishkon. Ahmad Karami, the author and preface of the edition. 1987.

14. Bobokalonov S. Art and genre features of Khodja Ismat's company. Nom.diss Sam., 2011.

15. Bobokalonov S., Raupova R. The spiritual heritage of Khoja Ismatullo Bukhari. Bukhara 2009.

16. Karimov I.A. Great and sacred independent homeland. Uzbekistan, T.: 2013.

\footnotetext{
${ }^{4}$ Каримов И.А. Буюк ва муқаддассан мустақил ватан. "Ўзбекистон”, Т.:
} 